УДК 82.091: 821.161.2+821.111

DOI: $10.31471 / 2304-7402-2019-3(55)-139-149$

\title{
POSITIVISM VS NEGATIVISM AS AN ARTISTIC IMPULSE (COMPARATIVE APPROACH TO IVAN BAHRIANYI AND GEORGE ORWELL WORKS)
}

\author{
S. S. Kobuta \\ Vasyl Stefanyk Precarpathian National University; \\ 76018, Ivano-Frankivsk, Shevchenko St., 57
}

The given article deals with the problem of comparison of literary and political works of Ivan Bahrianyi and George Orwell, as well as with an objective to prove that these two writers make up a far from random parallel for comparison.

On the basis of scientific works it proves that one can trace a genetic similarity in the main ideas highlighted in a number of works by these two writers. Both of them had a kind of indirect dialogue on the topics of freedom, equality and struggle against anti-humane regimes.

The article also highlights the fact that there is more to the indirect dialogue of Ivan Bahrianyi and George Orwell than it seems. Biographical insight used for the research proves that both men faced similar struggles in their lives, their political views were really close and their interpretation of the ongoing events serves as evidence. Consequently the article brings to attention the fact that biographies of the writers might become a key for understanding their works and positions. Another fact to support the above-given idea is that both writers use their own lives and personal experience as a basis for literary interpretation; this was proved by the researches of both George Orwell and Ivan Bahrianyi literary heritage. As a result we can research their works from the point of comparative typology in synchrony on the double grounds: the indirect dialogue about crucial human problems (mainly a solitary personal struggle against totalitarian regime) as well as usage of a similar artistic method to bring it to their audience.

The article deals with the problem of freedom as a core problem highlighted in literary and political works of Ivan Bahrianyi and George Orwell. It traces similarities and differences in the authors' perception of the notion and ways it changes in various circumstances. It proves that the Ukrainian author pays more attention to the national aspect of freedom than his British counterpart does, which might be explained both by the differences in the worldviews (Ivan Bahranyj always defined himself as a socialistic patriot, while George Orwell often was perceived as a generalist and the citizen of the world) and by the political conditions of the nations the writers represent. In terms of personal freedom both authors claim it to be a crucial value for

ISSN 2304-7402. Прикарпатський вісник НТШ. Слово. - 2019. - № 3(55). 
every person as it is closely connected with notions of dignity, self-respect, dreams realization etc. and defines the very existence of humankind.

Generally the article emphasizes the role and place of the writers in the anti-totalitarian discourse of the XX century. It draws attention to the fact that Ivan Bahrianyi and George Orwell devoted all their lives and literary efforts to the struggle for a free personality, who is not to be oppressed by any political regime. To achieve this goal they employed completely opposite methods, using positivism and negativism consequently as their basic artistic impulses. Though their ways of describing world phenomena were different the impact of their works and recipients' perception of their main ideas is the same.

Key words: Ivan Bahrianyi, George Orwell, typological approach, genetic similarity, indirect dialogue, freedom, liberty, anti-totalitarian discourse, dignity, biographical approach.

Introduction of the problem and data analyses Comparative literature has a complex nature, as it is based mainly on the correlation of literatures on a certain level of their development. It takes into account different periods, styles, individual positions and general tendencies. This is the main reason the modern typological approach as the constituent part of the latter deserves studying, in terms of mutual influence of international and national. According to A. Dima, any comparison of the former and the latter creates conditions capable of better revealing peculiarities of each of the literatures ${ }^{1}$. This way comparison can be performed in contrast in order to prove or dismiss any concert put forward by an inquisitive researcher.

Following the position of the Ukrainian researcher L. Oliander, all the national literatures are numerously interconnected through personalities of national writers who cooperate with literary worlds of other writers ${ }^{2}$. Therefore their study facilitates both national and world sciences, as well as it helps to reveal peculiarities of the world literary process development.

Quite often it happens that the object of comparative study is chosen of the basis of the direct or indirect dialogue which exists between writers. L. Oliander talks about several groups of dialogues: direct (1), i.e. a direct dialogue and communication between two writers; indirect (2), i.e. it is conducted through the thesaurus of a recipient, a dialogue between literary phenomena that appeared independently from one another; mixed forms of dia-

\footnotetext{
1 Дима А. Принципы сравнительного литературоведения / А.Дима. - М.: Издательство «Прогресс», 1977. - 227 с. - С. 190.

2 Оляндер Л. Проблеми міжлітературного діалогізму: компаративістський аспект / Л. Оляндер / Літературознавча компаративістика. Навчальний посібник / Ред. Р.Т. Громяк, І.В. Папуша. - Тернопіль: Редакційно-видавничий відділ ТДПУ, 2002. - 331с. - С. 20-28. - C.21.
}

ISSN 2304-7402. Прикарпатський вісник НТШ. Слово. - 2019. - № 3(55). 
logues $(3)^{3}$. The notion of the indirect dialogue attracts particular attention as it usually arises around general humane problems and events, e.g. world wars, ecology, world catastrophes, totalitarianism etc. ${ }^{4}$. The reasons of similarities and differences usually result from «common and different historical circumstances» in which works under question were created ${ }^{5}$. In this context all the similarities provide the grounds to claim there exists a single picture of the world literature process, and it serves as a setting for visible national differences ${ }^{6}$.

The subject of this article is the problem of a free person in the works of Ivan Bahrianyi and George Orwell, while the objective of the article is to research into the notions of positivism and negativism of the authors as their literary impulse and to investigate the connection between the impulse chosen and the recipients reaction. Literary works of both authors take part in the first part and middle of the XX century, when the whole world faced fundamental geopolitical as well as anthropological changes. These changes brought on a fresh approach to eternal issues and motives, as well as the place of a human in the world.

Main body Similarities and parallels in the fates, worldviews and general impact of the works of Ivan Bahrianyi and George Orwell provide solid grounds for typological comparison of their works, and this is to be done on the levels of themes and ideas. Both authors were convinced socialists in their political views, but they became bitterly disappointed in the social ideas being put into real life ${ }^{78}$, (especially on the examples of the USSR and the Social Revolution in Spain). R. Williams, who is a well-known researcher of George Orwell artistic personality, emphasized that the general effect of the latter's works is the paradox effect. He points out that the author was a socialist who popularized a fierce and destructive criticism of socialism, believed in equality and confronted class system, but in his works he highlighted the idea of

\footnotetext{
${ }^{3}$ Оляндер Л. Проблеми міжлітературного діалогізму: компаративістський аспект / Л. Оляндер / Літературознавча компаративістика. Навчальний посібник / Ред. Р.Т. Громяк, І.В. Папуша. - Тернопіль: Редакційно-видавничий відділ ТДПУ, 2002. - 331с. - С. 20-28. - С. 21.

${ }^{4}$ Ibid. - C. 22.

5 Брайко О. Українська компаративістика другої половини XX - початку XXI ст. / Національні варіанти літературної компаративістики / Національна академія наук України; Ін-т літератури ім. Т.Г.Шевченка; Д.С. Наливайко, Т.Н. Денисова, О.В. Дубініна та ін. - К.: Видавничий дім «Стилос», 2009. - С. 386-439 - С. 387.

${ }^{6}$ Дима А. Принципы сравнительного литературоведения / А.Дима. - М.: Издательство «Прогресс», 1977. - 227 с. - С. 166

7 Войчишин Ю. Іван Багряний. Літературно-бібліографічна студія / Ю.Войчишин / Українська вільна академія наук. Серія Література. Ч.10. - Вінніпег, Оттава, 1968. - 90 с. C.

8 Freeguard Gavin, Orwell Lecture 2007 [Електронний ресурс] Режим доступу: http://theorwellprize.co.uk/news/gavin-freeguard-orwell-lecture-2007/
}

ISSN 2304-7402. Прикарпатський вісник НТШ. Слово. - 2019. - № 3(55). 
natural inequality and inevitable class system ${ }^{9}$. As M. O'Connor puts it «he was also a man of tremendous contradictions. A self-proclaimed socialist, the young Blair would often complain about the repugnant condition in which the lower classes lived, particularly deriding them for their odor» ${ }^{10}$. Both Ivan Bahrianyi and George Orwell left their motherlands, and in both cases, their choice was only partially voluntary ${ }^{11},{ }^{12}$. Both authors were radical critics of the contemporary political regimes and they were not afraid to express their points of view freely, therefore they often became targets of criticism in press. Their works, publicist ones in particular, were not just objected and defamed, but also misused and wrongly cited.

Interaction of these authors happens mainly in the form of the indirect dialogue on the topic which is important for both of them - freedom. As far as we know there was no direct contact between these two authors, but, as it is noted by Ivan Dziuba, it was Ivan Bahrianyi, who initiated and organized the Ukrainian publication of «Animal Farm», a famous satire-dystopia by George Orwell, and it was the very first translation of the work into a foreign language ${ }^{13}$. Apart from this fact, under the analyses, some of the images used by Ivan Bahrianyi in his publicist works prove to be allusions on George Orwell works, in particular, his dystopian novel «1984»; this fact allows to see the indirect dialogue, which is built not only on the common problems, but works of authors as well.

Another reason for typological comparison of the works of these authors is so-called double biographical approach. On the one hand we are talking about parallelism in lives of Ivan Bahrianyi and George Orwell that influenced similarity of their worldview. On the other hand both authors used biographical method as a creative impulse. Works, especially novels, of both authors are based mainly on their personal experience ${ }^{14},{ }^{15}$. M.Spodarets, who was researching the problem and genre and style peculiarities of prose of Ivan Bahrianyi, came to a conclusion that it consists of new prose genres (novelpamphlet and a political novel) and original structure of the main character as

\footnotetext{
${ }^{9}$ Michael O'Connor Review of Gordon Bowker's "Inside George Orwell" [Електронний ресурс] Режим доступу:http://www.netcharles.com

${ }^{10}$ Williams Raymond, Culture and Society, Columbia University Press, 1983 p. 362p. - P. 286.

${ }^{11}$ Правдюк О. Куркульським шляхом / О.Правдюк / Багряний І. Вибрані твори / Упоряд., автор передм. та приміток М. Балаклицький. - К.: Смолоскип, 2006. - С. 506-520.

${ }_{12}$ Taylor D. J. Review of Emma Larkin's "Secret Histories: Finding George Orwell in a Burmese Teashop" The Sunday Times, 22 August 2004 [Електронний ресурс] Режим доступу: http://www.netcharles.com/ orwell/articles/col-burmeseteashop.htm

13 Дзюба І. Бронебійна публіцистика. Іван Багряний. [Електронний ресурс]. - Режим доступу: http://www.day.kiev.ua/uk/library/books/bronebiyna-publicistika-ivan-bagryaniy

14 Чекаліна В. «Ми є. Були. I будем ми. Й Вітчизна наша 3 нами» // «Кримська Світлиця». - 2006. - № 9. - 24 лют. / [Електронный ресурс] - Режим доступу: http://svitlytsia.crimea.ua/?section=article \&artID $=3635$

15 There's more to George Orwell than politics [Електронний ресурс] Режим доступу: http://www.guardian.co.uk/books/booksblog/2010/jan/21/ more-to-george-orwell-politics
}

ISSN 2304-7402. Прикарпатський вісник НТШ. Слово. - 2019. - № 3(55). 
well as an autobiographical phenomenon ${ }^{16}$. In our opinion, similar features are characterizing the works of George Orwell. Though literary and artistic methods of the authors often differ, they are united by a similar way of thinking and ideology of their works. Therefore genetic kinship, which is understood as a simultaneous appearance of the same theme in different literatures and works of different authors as a result of certain historical events influence, becomes one of the basis of typological similarity in their works.

As it was stressed above, a crucial idea of the Ivan Bahrianyi and George Orwell works is a human striving for freedom in all of its possible meanings. O. Pererva characterizes Ivan Bahrianyi as a writer who was born to be free and proud, who sacrificed his talent, love and courage in a struggle against totalitarianism and cruelty of dominant regimes, against slave-like psychology of his fellow citizens ${ }^{17}$. R. Williams claims that prose written by George Orwell is closely connected to freedom and social opportunity of $\operatorname{truth}^{18}$, because the author in question belong to those people, who found themselves in a fight for independence ${ }^{19}$.

Both Ivan Bahranyj and George Orwell try to reveal the importance of freedom in all of its aspects, freedom of a personality on the background of spiritual, social and political phenomena. They are united by their common belief in a person, in his undefeatable spirit, courage and kindness ${ }^{20},{ }^{21}$. While studying the works of these two authors, most researchers pay a lot of attention to their interpretation of personal freedom in the circumstances of a totalitarian regime, and it is only natural as works of the writers were heavily influence by the historical period they witnessed. Anti-totalitarian discourse of Ivan Bahrianyi and George Orwell shows itself as a logical reaction on the political situation in the world, as the very existence of anti-humane regimes could not come unnoticed and leave its imprint on human consciousness and in literature as well. Following O. Bodnar, we agree that George Orwell and Ivan Bahrianyi belong to the generation of writers who demonstrated a brutal introduction and interference of politics in literature ${ }^{22}$.

\footnotetext{
${ }^{16}$ Балаклицький М. «Нова релігійність» Івана Багряного: Монографія / М. Балаклицький. - К.: Смолоскип, 2005. - 167 с. -С. 22

${ }^{17}$ Пасічник О.В. Образ світу і концепція героя у творчості Уласа Самчука й Олександра Солженіцина в'язнично-таборової тематики [Текст]: авторефер. дис... канд. філол. наук. 10.01.05 - порівняльне літературознавство, Тернопільський національний педагогічний університет ім. Володимира Гнатюка. Тернопіль, 2004. 20с. - укр.

${ }^{18}$ Williams Raymond, Culture and Society, Columbia University Press, 1983 p. 362p. -P.288

${ }^{19}$ Ibid. -P.289

${ }^{20}$ Гришко В. Невгасна віра в людину / Багряний І. Вибрані твори / Упоряд., автор передм. та приміток М. Балаклицький / Іван Багряний. - К. : Смолоскип, 2006. - С.579-599.

${ }^{21}$ King Steve, Orwell's Warning [Електронний peсурс] Режим доступу: http://bnreview. barnesandnoble.com/t5/Daybook/Orwell-s-Warning/ba-p/5023

${ }^{22}$ Боднар О. І. Художньо-публіцистичні візії тоталітаризму у творчості М.Рудницького та Дж. Орвелла [Текст]: рецептивно-комунікативний аспект. Автореф. дис... канд. філол. наук: 10.01.05 - порівняльне літературознавство / Боднар Олег Ігорович; Тернопільський національний педагогічний університет ім. Володимира Гнатюка. Тернопіль, 2012. - 20с. - укр. -С. 1
}

ISSN 2304-7402. Прикарпатський вісник НТШ. Слово. - 2019. - № 3(55). 
A high level of political consciousness of Ivan Bahrianyi and George Orwell and their desire to depict ongoing processes in literature are not solitary responsible for the literary criticism of totalitarianism in the works of these authors. They also paid attention to the influence of anti-humane regimes the processes of self-realisation and self-defining, therefore their works emphasize all the destructive consequences of the freedom repression and limitation for a personality. According to V. Kokhanovsky, a person will never willingly accept a social regime that limits their right to be free ${ }^{23}$. Both Ivan Bahrianyi and George Orwell show a characteristic wish to depict all the negative consequences of the Marxist and Nazi ideas realization, as they lead to depreciation of a personality. According to V. Myronov, a purely dogmatic interpretation of Marxist ideas causes absolute annihilation of individual in order to reach communal and social ${ }^{24}$. This idea of forced equality presented itself as the basis for socialism, as a result inner freedom was neglected and the very idea of it was considered wrong, because a common person was treated as a "part of a mechanism" in a big bureaucratic and administrative system $^{25}$.

It would be absolutely wrong, though, to claim that civil and literary works of the authors under study are all about criticism of political regimes, with no other ideas. Ivan Bahranyj is a citizen of a socialistic country, who tries to show the world all the downsides and injustice of the system from the point of view of an insider. At the same time the author protests not against a communist utopia, but against a lopsided way in has been put into life. He emphasizes that there hides a hideous reality behind beautiful and attractive slogans, and more than that, these slogans cost a lot of lives. To put it differently, he protests against the system that deprives a person the right to be free. It is important to stress that according to Ivan Bahrianyi freedom is not determined by the external factors only. On the contrary, while external freedom often depends on the social environment and other outer conditions, it is the inner freedom and integrity and values which form the core of a person. This writer also pays special attention to national freedom and defines it as a crucial condition of the freedom of person fulfillment. According to A. Dima, there are literatures which have a significant striving to universality of general-European unity, while the other literatures tend to be more nationally closed $^{26}$. In our opinion, Ivan Bahrianyi represents the latter type of literature, as he claimed himself that one of the tasks of a contemporary Ukrainian

\footnotetext{
${ }^{23}$ Кохановский В.П. Философия (Учебное пособие) / [Електронний ресурс]. - Режим доступу: http://royallib.ru/book/kohanovskiy_valeriy/filosofiya_uchebnoe_posobie.html

${ }^{24}$ Миронов В. Философия: Учебник для вузов / Под общ. ред. В. В. Миронова. - М.: Норма, 2005. - 673 с. -C. 659

${ }^{25}$ Миронов В. Философия: Учебник для вузов / Под общ. ред. В. В. Миронова. - М.: Норма, 2005. -673 с. -C. 667

${ }^{26}$ Дима А. Принципы сравнительного литературоведения / А.Дима. - М.: Издательство «Прогресс», 1977. - 227 с. - С. 166
}

ISSN 2304-7402. Прикарпатський вісник НТШ. Слово. - 2019. - № 3(55). 
writer is national self-affirmation ${ }^{27}$. The reason for this, as H. Malanij claims, was the fact that Ukrainian intellectual circles were urged by the stateless state of Ukraine as an independent country, therefore they tried to affirm Ukrainian originality and were looking for practical ways to make Ukrainian integrity a reality, as a result these aspirations influenced literary and creative works of writers and artists ${ }^{28}$.

This is all closely connected with the key tone both of the authors choose to write in. They are completely opposite judging the style, information delivery and final message. As E. Weinberger puts it «Orwell is tiresome and negative, and might have profited from a little easygoing complacency» ${ }^{29}$. At the same time Ivan Bahrianyi is noted as one of the greatest optimists of the period. While the British author tells «tales of woebegotten souls who achieve freedom at great personal risk and sacrifice only to see that freedom stripped away through deception and cheating $\rangle^{30}$, the Ukrainian writer proves it right to fight till the victorious end, which the readers clearly understands from all of his novels. The marvelous thing about both authors this is that their warnings and literary works suggest Bahrianyi and Orwell are still alive. Their positivism and negativism consequently send a special message to the readers to never give up, but go and change the world injustices around them. While the artistic impulses of the writers contradict each other, we can witness a certain opposition of encouragement and hopeless criticism, the final impact of their literary works proves to be the same.

Conclusion Summing it up, Ivan Bahrjany was never considered a convenient author for Soviet reality. He discarded idea of liberties and inner freedom of a person who represented a nation without a national state. This writer's characters are spiritually free in the conditions of physical oppression, but when they break free from their oppressors, there comes into action so-called «Motherland gravity». They want their land to be independent, only then will they feel self-sufficient and free indeed. In this aspect characters of the Ivan Bahrianyi resemble the writer himself, as in the Soviet reality he was a non-conformist, defined by his national devotion and persistence in the idea that every personality is equally important.

\footnotetext{
27 Багряний І. Розгром: Повість-вертеп / Багряний І. Вибрані твори. Т.2. - К.: Юніверс, 2006. - С. 527-652.

${ }^{28}$ Маланій Н.І. Типологія екзистенціалів війни в українсько-німецькому літературному просторі (на матеріалі прозових творів про Другу Світову війну) [Текст]: автореф. дис... канд. філол. наук. 10.01.05 - порівняльне літературознавство, Тернопільський національний педагогічний університет ім. Володимира Гнатюка. - Тернопіль, 2011. 20 c. - C. 6

${ }^{29}$ Weinberger Eric Contrarian of note: an Orwell defense in brief chapters [Електронний peсурс] Режим доступу: http://www.netcharles.com/orwell/articles/col-contrarianofnote.htm

30 Michael O'Connor Review of Gordon Bowker's "Inside George Orwell" [Електронний pecypc] Режим доступу: http://www.netcharles.com
}

ISSN 2304-7402. Прикарпатський вісник НТШ. Слово. - 2019. - № 3(55). 
George Orwell was not a convenient author as well. D. Taylor, who was researching his works, claims that form the point of view of the writer a common person values privacy more than other states or conditions ${ }^{31}$, and this was what defined the main idea of his work. National self-affirmation is not foreign to George Orwell, but it is much less prominent in his works, comparing them to the works of Ivan Bahrianyi. D. Kerr writes that George Orwell was «the citizen of the world» ${ }^{32}$. At the same time A. Zverev claims that in in his civil and publicist works George Orwell made a central topic of British mass psychology, character and national type ${ }^{33}$. Consequently, though this author often takes a cosmopolitical position, his British origin reveals itself in the «inborn morals» and worldview values. It influences the writer's characters directly: their main features are not intelligence and spiritual superiority, but a sense of dignity. George Orwell treats freedom as a spiritual and psychological notion, which finds its realization in a person being faithful to them. He might consider a free person not being tied to some country, but external freedom is crucial in his perception, it is perceived as given. Contrary to Ivan Bahrianyi, who views freedom from romantic but maximalist positions, and who is ready to sacrifice a lot for it, George Orwell considers it acceptable to turn to social-economic escapism or conformism under the conditions of inner integrity being kept intact.

To sum up, events of the interwar period of the XX century caused a serious literary and artistic feedback, they made writers analyse a lot of negative phenomena of the time and show it in their literature, therefore they created a common ground for an indirect dialogue between Ivan Bahrianyi and George Orwell. These authors had a similar life ways and worldviews, and it gives the grounds to talk about certain parallelism in their works, and they reveal themselves primarily in the choice of themes and main ideas. The main value for both of the authors was freedom of a person and possibility to save one's personality in the anti-humane ideas. This all resulted in their works becoming the example of ine of the most powerful anti-totalitarian discourse, because both Ivan Bahrianyi and George Orwell understood that the most dreadful thing about totalitarianism is its urge for freedom deprivation, and freedom is the very core of a human. Literary works of these authors are considered to be the literary manifesto of a human dignity, and one can find a problem of freedom touched upon in every work of the writers. It gives us grounds to talk about existence of an ideal of «a free person» of Ivan Bahrianyi and George Orwell, which finds its realization in literature through a "free person" conception.

\footnotetext{
${ }^{31}$ Taylor D. J. Big Brother - George Orwell Reflects, The Independent, 2002 [Електронний pecyрс] Режим доступу: http://theorwellprize.co.uk/george-orwell/about-orwell/d-j-taylorbig-brother-george-orwell-reflects/

${ }^{32}$ Kerr Douglas Orwell, Kipling, and Empire September-December 2008[Електронний ресурс] Режим доступу:www.finlay-publisher.com

33 Зверев А.М. О старшем брате и чреве кита / А.М.Зверев // Литературное обозрение. 1989. - №9. - C. 56-61.
}

ISSN 2304-7402. Прикарпатський вісник НТШ. Слово. - 2019. - № 3(55). 


\section{Лimepamypa}

1. Bahrianyi I. Rozghrom: Povist-vertep / Bahrianyi I. Vybrani tvory. T.2. K.: Yunivers, 2006. - S.527-652. ((in Ukrainian)

2. Bodnar O.I. Khudozhno-publitsystychni vizii totalitaryzmu u tvorchosti M.Rudnytskoho ta Dzh. Orvella [Tekst]: retseptyvno-komunikatyvnyi aspekt. Avtoref. dys... kand. filol. nauk: 10.01.05 - porivnialne literaturoznavstvo / Bodnar Oleh Ihorovych; Ternopilskyi natsionalnyi pedahohichnyi -universytet im. Volodymyra Hnatiuka. Ternopil, 2012. - 20s. - ukp. (in Ukrainian)

3. Braiko O. Ukrainska komparatyvistyka druhoi polovyny KhKh - pochatku KhKhI st. / Natsionalni varianty literaturnoi komparatyvistyky / Natsionalna akademiia nauk Ukrainy; In-t literatury im. T.H.Shevchenka; D.S. Nalyvaiko, T.N. Denysova, O.V. Dubinina ta in. - K.: Vydavnychyi dim «Stylos», 2009. - S. 386-439 (in Ukrainian)

4. Dyma A. Pryntsypy sravnytelnoho lyteraturovedenyia / A.Dyma. - M.: Yzdatelstvo «Prohress», 1977. - $227 \mathrm{~s}$.

5. Dziuba I. Bronebiina publitsystyka. Ivan Bahrianyi. [Elektronnyi resurs]. Rezhym dostupu: http://www.day.kiev.ua/uk/library/books/bronebiynapublicistika-ivan-bagryaniy (in Ukrainian)

6. Freeguard Gavin, Orwell Lecture 2007 [Elektronnyi resurs]. - Rezhym dostupu : http://theorwellprize.co.uk/news/gavin-freeguard-orwell-lecture-2007/

7. Hryshko V. Nevhasna vira v liudynu / Bahrianyi I. Vybrani tvory / Uporiad., avtor peredm. ta prymitok M. Balaklytskyi / Ivan Bahrianyi. - K.: Smoloskyp, 2006. - S.579-599. (in Ukrainian)

8. Kerr Douglas Orwell, Kipling, and Empire September-December 2008 [Elektronnyi resurs]. - Rezhym dostupu: www.finlay-publisher.com

9. King Steve, Orwell's Warning [Elektronnyi resurs]. - Rezhym dostupu: http://bnreview.barnesandnoble.com/t5/Daybook/Orwell-s-Warning/ba$\mathrm{p} / 5023$

10. Kokhanovskyi V.P. Fylosofyia (Uchebnoe posobye) / [Elektronnyi resurs]. - Rezhym dostupu: http://royallib.ru/book/kohanovskiy_ valeriy/ filosofiya_uchebnoe posobie.html (in Russian)

11. Malanii N.I. Typolohiia ekzystentsialiv viiny $\mathrm{v}$ ukrainsko-nimetskomu literaturnomu prostori (na materiali prozovykh tvoriv pro Druhu Svitovu viinu) [Tekst]: avtoref. dys... kand. filol. nauk. 10.01.05 - porivnialne literaturoznavstvo, Ternopilskyi natsionalnyi pedahohichnyi universytet im. Volodymyra Hnatiuka. - Ternopil, 2011. - 20 s. (in Ukrainian)

12. Myronov V. Fylosofyia: Uchebnyk dlia vuzov / Pod obshch. red. V.V. Myronova. - M.: Norma, 2005. - 673 s. (in Russian)

13. O'Connor Michael Review of Gordon Bowker's «Inside George Orwell» [Електронний ресурс] Режим доступу: http://www.netcharles.com/orwell/ articles/col-insidegeorgeorwell.htm

14. Oliander L. Problemy mizhliteraturnoho dialohizmu: komparatyvistskyi aspekt / L.Oliander / Literaturoznavcha komparatyvistyka. Navchalnyi

ISSN 2304-7402. Прикарпатський вісник НТШ. Слово. - 2019. - № 3(55). 
posibnyk / Red. R.T.Hromiak, I.V.Papusha. - Ternopil : Redaktsiinovydavnychyi viddil TDPU, 2002. - 331s. - S. 20-28. (in Ukrainian)

15. Pravdiuk O. Kurkulskym shliakhom / O.Pravdiuk / Bahrianyi I. Vybrani tvory / Uporiad., avtor peredm. ta prymitok M. Balaklytskyi. - K.: Smoloskyp, 2006. - S.506-520. (in Ukrainian)

16. Taylor D.J. Big Brother - George Orwell Reflects, The Independent, 2002 [Elektronnyi resurs]. - Rezhym dostupu: http://theorwellprize.co.uk /georgeorwell/about-orwell/d-j-taylor-big-brother-george-orwell-reflects/

17. Taylor D.J. Review of Emma Larkin's "Secret Histories: Finding George Orwell in a Burmese Teashop" The Sunday Times, 22 August 2004 [Elektronnyi resurs]. - Rezhym dostupu: http://www.netcharles.com/ orwell/articles/col-burmeseteashop.htm

18. Voichyshyn Yu. Ivan Bahrianyi. Literaturno-bibliohrafichna studiia / Yu.Voichyshyn / Ukrainska vilna akademiia nauk. Seriia Literatura. Ch.10. - Vinnipeh, Ottava, 1968. - 90 s. (in Ukrainian)

19. Weinberger Eric Contrarian of note: an Orwell defense in brief chapters [Електронний ресурс] Режим доступу: http://www.netcharles.com/ orwell/articles/col-contrarianofnote.htm

20. Williams Raymond, Culture and Society, Columbia University Press, 1983 p. 362p.

21. Zverev A.M. O starshem brate y chreve kyta / A.M.Zverev // Lyteraturnoe obozrenye. - 1989. - №9. - S. 56-61. (in Russian)

Стаття надійшла до редакиійної колегії 4.03.2019 p.

Рекомендовано до друку д.ф.н., професором, академіком НАНУ Рудницьким Л. I.

\title{
ПОЗИТИВІЗМ VS НЕГАТИВІЗМ ЯК ХУДОЖНІЙ ІМПУЛЬС (КОМПАРАТИВНИЙ ПІДХІД ДО ТВОРЧОСТІ ІВАНА БАГРЯНОГО ТА ДЖОРДЖА ОРВЕЛЛА)
}

\author{
C. C. Кобута \\ Прикарпатський національний університет імені Василя Стефаника; \\ кафедра іноземних мов і перекладу; \\ вул. Шевченка 57, 76000, Івано-Франківськ, Україна
}

Стаття присвячена проблемі порівняння творчості Івана Багряного та Джорджа Орвелла, а також виявлення літературного та біографічного підгрунтя для їх зіставлення у синхронії. Метою даного дослідження є співставлення діаметрально протилежних авторських методів письменників заради досягнення ідентичної мети. Зокрема, мова йде про так звані негативізм та позитивізм як творчі імпульси авторів, котрі повинні викликати у читача бажання діяти, втілювати свої ідеї та змінювати світ довкола.

ISSN 2304-7402. Прикарпатський вісник НТШ. Слово. - 2019. - № 3(55). 
В основній частині наукової розвідки проаналізовано літературні особистості авторів (на основі біографічних та літературознавчих досліджень вітчизняних та закордонних науковців), а також встановлено, щзо застосування біографічного підходу для вивчення $і$ трактування їх публіцистичних і художніх творів дає змогу краще зрозуміти і точніше виділити основні проблеми та ідеї творчості авторів. Особлива увага приділясться літературній критиці та характеристиці творчості Івана Багряного та Джсорджа Орвелла, котрі не лише прямо вказують на домінантні риси у творах обох письменників, але й дають змогу зіставити авторські інтенції їхніх знакових романів та проаналізувати їх вплив на читача. Основна увага приділяється особливостям трактування понять волі та вільної людини в антитоталітарному дискурсі письменників, а також дослідженню передумов та причин ведення ними непрямого діалогу в художніх та публічистичних творах.

Вивчення та аналіз наукової критики, спрямованої на дослідження творчості та особистостей Івана Багряного та Джсоджа Орвелла, дає підстави стверджувати, щзо біографічний підхід дозволяє розкрити нові паралелі порівняння авторів, а також дозволяє краще зрозуміти основний посил їхніх творів. Протиставлення позитивізму Івана Багряного та негативізму Джорджа Орвелла як творчих імпульсів авторів, щзо безпосередньо впливають на рециипієнта, доводять, щзо протилежні методи у даному випадку приводять до однакового результату.

Ключові слова: Іван Багряний, Джордж Орвелл, типологічний підхід, генетична спорідненість, непрямий діалог, воля, свобода, анти тоталітарний дискурс, гідність, біографічний підхід. 